\title{
長期間平均の沿岸漂砂量の岸沖分布
}

\section{Cross-shore Distribution of Long-Term Average Longshore Sediment Transport Rate}

\author{
栗山善昭 ${ }^{1} \cdot$ 坂本 光 $^{2}$ \\ Yoshiaki KURIYAMA and Hikari SAKAMOTO
}

\begin{abstract}
Cross-shore distributions of longshore sediment transport rate at the Hasaki Coast of Japan for 15 years from 1987 to 2001 were estimated with a one-dimensional numerical model and the cross-shore distribution of the long-term average longshore sediment transport rate was examined. The model was calibrated with longshore current velocities measured with a spherical float once a day at about 50-m intervals along a 427-meter-long pier at the study site. Numerical simulations showed that the average longshore sediment transport rate was northward near the shore, but southward away from the shore.
\end{abstract}

\section{1.はじめに}

長期間平均の沿岸漂砂（以下，平均沿岸漂砂）は，長 期地形変化の原因となることから，その把握は土砂収支 検討あるいは海岸管理において重要である．汀線近傍の 平均沿岸漂砂の方向は構造物周辺の地形変化より把握す ることが可能である．構造物の漂砂上手側で堆積が生じ, 下手側で侵食が生ずる．しかし，汀線近傍よりも沖の平 均沿岸漂砂については情報が少なく，Sato（1996）によ って岸と沖では平均沿岸漂砂の方向が異なる可能性が示 されているものの，平均沿岸漂砂の岸沖分布に関しては 不明な点が多い。そこで，本研究では，茨城県波崎海岸 を対象とし，沿岸漂砂量の岸沖分布を 2 時間ごとに 15 年間分計算し，それらを平均することにより平均沿岸漂 砂量の岸沖分布を求め，その特性を検討した。

\section{2. 沿岸漂砂量推定数值シミュレーションモデル}

本研究で用いたモデルは，沿岸方向に地形が一様であ るとの仮定の下での波の変形と波の谷の位置より下方に 抒ける鉛直方向平均の沿岸流速，および沿岸漂砂量を推 定する 1 次元モデルであり，波浪変形サブモデル，沿岸 流速推定サブモデル，沿岸漂砂量推定サブモデルの 3 つ のサブモデルより構成されている．沿岸漂砂量の計算で は，まず，栗山・中官（1999）によって開発された波浪 変形サブモデルと沿岸流速推定サブモデルを用いて一つ の不規則波群を構成する個々波の変形および個々波每の 沿岸流速を計算し，その計算結果を基に，一つの不規則 波群の有義波高と時間平均の沿岸流速を求める. 続いて, 時間平均の波浪特性, 沿岸流速を用いて沿岸漂砂量サブ モデルから沿岸漂砂量を計算する．波浪変形サブモデル については栗山・中官（1999）に詳述されているので,

1 正会員 博(工) (独法)港湾空港技術研究所漂砂研究室 2 正会員 $\quad$ (株)プライア・コンサルタント設計部
本章では，残りの二つのサブモデルの概要を説明する.

（1）沿岸流速推定サブモデル

個々波の時間平均の沿岸流速 $U_{\text {ind }}$ は，以下の運動量 方程式，すなわ方摩擦項 $F_{x}$ と radiation stress 項 $R_{x}$, 風応力項 $W_{x}$, surface roller による運動量フラックス項 $M_{x}$ ，水平拡散項 $L_{x}$ の鈞り合い式によって求める.

$$
F_{x}+R_{x}-W_{x}+M_{x}-L_{x}=0
$$

Radiation stress 項としては微少振幅波理論より求ま る式を用い，風応力項は以下の式で推定する.

$$
W_{x}=C_{d} \rho_{a} W_{v}^{2} \sin \alpha_{w} /\left(\rho_{w} h\right)
$$

ここで, $C_{d}$ は無次元係数, $\rho_{a}$ は空気の密度, $W_{v}$ は風 速， $\alpha_{w}$ は風向， $\rho_{w}$ は海水の密度， $h$ は水深である. 係 数 $C_{d}$ は栗山ら（2005）にならい，0.0022 とした。

Surface roller 項 $M_{x}$ は，波のトラフょり上方の時間 平均の岸沖流速分布として三角形分布，すなわち surface roller の底面で 0 , 頂部で波速 $C$ となる速度分布を 仮定したときの surface rollerの運動量フラックス $M_{r}$ を使って次式で評価する.

$$
M_{x}=\frac{1}{\rho_{w} h}\left(\frac{\partial M_{r}}{\partial y}\right), M_{r}=-\frac{1}{3} \rho_{w} C^{2} \frac{A_{r}}{L} \cos \theta \sin \theta
$$

ここで, $y$ は沖方向距離, $L$ は波長, $\theta$ は波向, $A_{r}$ は surface roller の面積であり，以下の方法で求める.

（a）Surface rollerの面積は波高の 2 乗に比例すると 仮定する。この仮定を基にして得られる surface roller の面積 $A_{r 1}$ は無次元係数 $C_{A}$ と波高 $H$ とを使って次式で 表される。

$$
A_{r 1}=C_{A} H^{2}
$$

無次元係数 $C_{A}$ は, イリバーレン数 $\xi_{b}$ の関数として 次式で表される. 


$$
\begin{aligned}
& C_{A}=17.0 \log \xi_{b}+24.7 \\
& \xi_{b}=\tan \beta / \sqrt{H_{1 / 3, b} / L_{1 / 3,0}}
\end{aligned}
$$

ここで, $\tan \beta$ は海底勾配, $H_{1 / 3, b}$ は研波有義波高, $L_{1 / 3,0}$ は有義波周期に対応した沖波波長である.

（b）ただし, surface roller の面積は surface roller の エネルギー減衰を０とした以下のエネルギー変換式 （6）より得られる surface rollerの面積 $A_{r 2}$ より大きく ならない。

$$
\begin{aligned}
& \frac{\partial\left(E_{w} C_{g}\right)}{\partial y}+\frac{\partial W_{r}}{\partial y}=0, \\
& W_{r}=\frac{1}{8} \rho_{w} C^{3} \frac{A_{r 2}}{L}
\end{aligned}
$$

ここで， $E_{w}$ は波のエネルギー， $C_{g}$ は群速度，Wr $W_{r}$ は波 のトラフより上方の流速分布として三角形分布を仮定し たときの surface roller のエネルギーフラックスを表し ている.

（c）Surface roller は波が再生した地点で消滅する.

実際の計算では，砕波してから波が再生するまでの区 間において，仮定（a）を基に得られる surface rollerの 面積 $A_{r 1}$ と仮定（b）を基に得られる $A_{r 2}$ の小さい方を その地点の surface rollerの面積とする.

水平拡散項は式 $(7)$ 上り求め, 水平拡散係数 $\varepsilon$ は Battjes (1975) と同様に波のエネルギー減衰，ここでは 個々波の surface rollerのエネルギー減衰を基に推定す る。

$$
\begin{aligned}
& L_{x}=\frac{\partial}{\partial y}\left(\varepsilon \frac{\partial U_{\text {ind }}}{\partial y}\right), \\
& \varepsilon=M h\left(\frac{D}{\rho_{w}}\right)^{1 / 3}, \ldots \ldots \ldots . . . \\
& D=\frac{\partial\left(E_{w} C_{g}\right)}{\partial y}+\frac{\partial W_{r}}{\partial y}
\end{aligned}
$$

ここで, $M$ は無次元係数であり, Kuriyama・ Ozaki (1996) が $M=5 \sim 10$ とすると実測值と計算值とがよく 一致することを示していることから，ここでは $M=5$ と した.

摩擦項 $F_{x}$ は，西村 (1982)によって示された波と流れ を考虑した次式より求める。

$$
\begin{gathered}
F_{x}=\frac{C_{f}}{h}\left(W+\frac{w_{b}^{2}}{W} \sin ^{2} \theta\right) U_{i n d}, \\
W=\left(\sqrt{U_{i n d}^{2}+w_{b}^{2}+2 U_{i n d} w_{b} \sin \theta}+\cdots \cdots\right. \\
\\
\left.\sqrt{U_{\text {ind }}^{2}+w_{b}^{2}-2 U_{\text {ind }} w_{b} \sin \theta}\right) / 2, \\
w_{b}=2 v_{m} / \pi, \quad v_{m}=\pi H /(T \sinh (2 \pi h / L))
\end{gathered}
$$

ここで， $C_{f}$ は無次元係数， $w_{b}$ は底面に扔ける波による 水粒子速度の振幅， $T$ は周期である。

無次元係数 $C_{f}$ に関しては, 栗山・中官 (1999) が,
$C_{f}=0.005$ とした本モデルが沿岸砂州周辺の沿岸流速 を精度良く再現することを確認している．しかし，Garcez-Faria ら（1998）は現地観測データを基に摩擦係数 は岸沖方向に一定ではないことを報告しており，さらに， 波崎海岸においても，その後の検討で摩擦係数を一定と すると砕波帯外における沿岸流速を過小評価してしまう ことが明らかとなった。

そこで, Garcez-Faria ら (1998)や Ruessink ら (2001) の研究にならい, 摩擦係数を水哚の関数 (式 $(9)$ ) 仮定し、計算值と実測值との誤差が最も小さくなるよう に粗度倸数 $k_{a}$ と無次元係数 $\alpha$ とを求めた。検討結果は 3. で述べる.

$$
C_{f}=0.011\left(\frac{k_{a}}{h}\right)^{1 / \alpha}
$$

（2）沿岸漂砂量推定サブモデル

沿岸漂砂量の推定では, 渡辺ら（1984）の三次元海浜 変形予測モデルにおいて流れによる漂砂量の推定に用い られている次式を使用した。

$$
\begin{aligned}
& Q=A\left(\tau_{b}-\tau_{c r}\right) U /\left(\rho_{w} g\right) \\
& \tau_{b}=\rho_{w} h F_{x} \ldots \ldots \ldots \ldots \ldots \ldots \ldots \ldots \ldots \ldots \ldots \\
& \tau_{c r}=\left(\rho_{s}-\rho_{w}\right) g d \Psi_{c r}
\end{aligned}
$$

ここで, $Q$ は沿岸漂砂量, $A$ は係数, $\tau_{b}$ は底面せん断 力， $\tau_{c r}$ は移動限界せん断力, $U$ は時間平均の沿岸流速, $g$ は重力加速度, $d$ は粒径, $\rho_{s}$ は底質の密度, $\Psi_{c r}$ は限 界シールズ数である．底面せん断力を推定する際に用い る $F_{x}$ は，波と流れの両方の影響を考慮している前述の 式（8）である.

\section{3. 浻岸流速推定サブモデルのキャリブレーション}

波崎海洋研究施設 (Hazaki Oceanographical Research Station, 以下 HORS ; 位置は図-1 参照)におい て 1987 年 1 月〜 2001 年 12 月にかけて取得された沿岸 流速デー夕を用いてモデルのキャリブレーションを行っ た. HORSでは, 長さ約 $400 \mathrm{~m}$ の観測栈橋に沿って, 休日を除く 1 日I回, 浮き（フロート）によって沿岸流 速を観測している(栗山ら，2005）。観測地点は，汀線 近傍の基準点からの沖方向距離（後述の図-2 参照）が $115 \mathrm{~m}, 145 \mathrm{~m}, 190 \mathrm{~m}, 240 \mathrm{~m}, 285 \mathrm{~m}, 330 \mathrm{~m}, 380 \mathrm{~m}$ の地点である.フロートによる沿岸流速の観測は簡単な 方法であるけれども，本方法によって沿岸流速を精度良 く測定できることは栗山ら（1992）が電磁流速計による 観測結果と本方法による観測結果とを比較することによ り確認している.

図-2 は 1 日 1 回の断面測量結果および年 1，2 回の深 浅測量結果を基にした観測期間中の平均断面を示したも のである．以下，観測栈橋上の位置は図-2の座標を基 


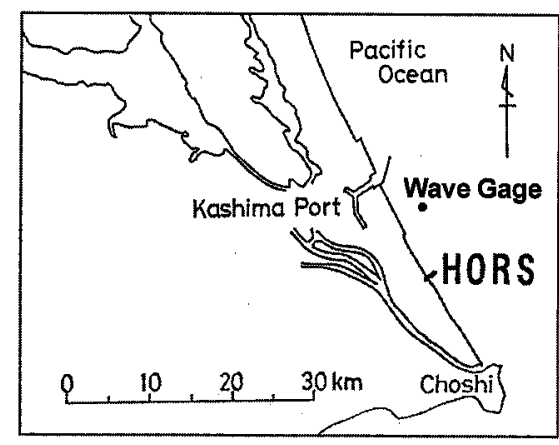

図-1 波崎海岸研究施設と沖波波高計の位置

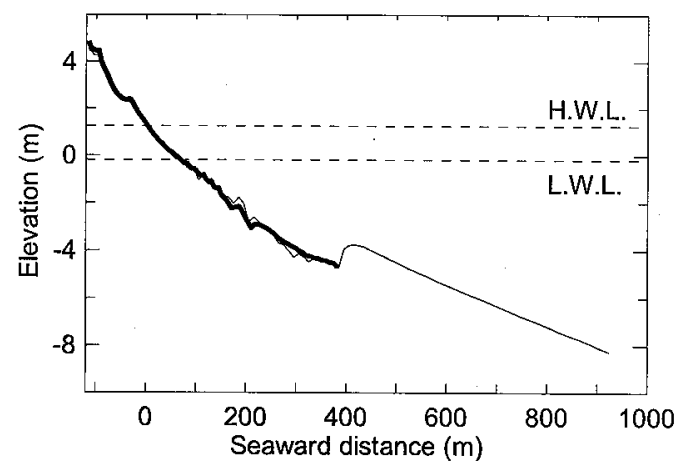

図-2 観測期間中の平均断面（波崎工事基準面基準）: 太い実線は断面测量結果を, 細い実線は深浅測量 結果を基にしている。

に示す（例えば，沖方向距離 $115 \mathrm{~m}$ の地点は $\mathrm{P} 115 \mathrm{~m}$ と 表す). 平均断面の海底勾配は汀線近傍では約 $1 / 40$ であ るものの沖へ向かうほど紱やかになり，P300 $\mathrm{m}$ 付近で は約 $1 / 100$ ，観測栈橋よりも沖（P400 m よりも沖）で は約 1/120 となっている．底質粒径は岸沖方向にほぼ一 栐であり，中央粒径は $0.18 \mathrm{~mm}$ である（加藤ら，1990）. 1986 年〜 1998 年に取得された 17 枚の深浅図を基にす ると, HORS 周辺の地形は沿岸方向にほほ一様である (Kuriyama, 2002).

沿岸流のほかには，観測栈橋先端で風向・風速を 1 時 間に 10 分間観測している. 沖波波高・周期は，鹿島港 沖の水深約 $24 \mathrm{~m}$ の地点 (図-1) において 2 時間間隔で 20 分間観測されている. 同観測地点では波向観測も行 われているものの，キャリブレーション期間には欠測が 比較的多かったことから, 沖波波向として, 橋本ら （1999）が，広範囲の風デー夕を入力データとし, 非線 形相互作用による波浪エネルギー伝達を定式化した WAM と呼ばれる第三世代波浪推算モデルを用いて推 定した值を用いる．ただし，沖波波向は沿岸流速に大き な影響を与えるものの，推算された沖波波向の精度が十 分に検討されているわけではない，そこで，本研究では
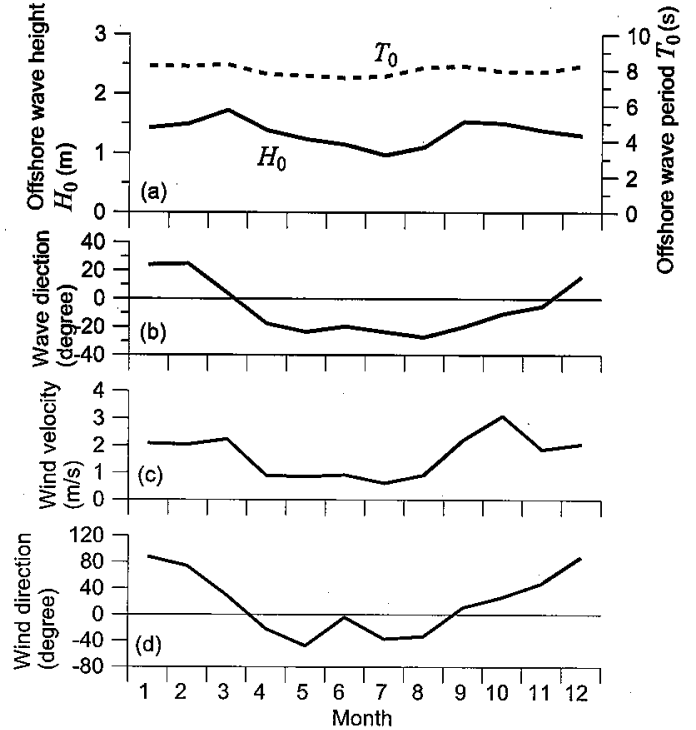

図-3（a) 沖波波高 - 周期，(b) 沖波波向，(c) 風速，(d) 風 向の月平均

沖波波向に一律, 補正角度 $\theta_{c}$ を加えることとし，この 值は沿岸流速の害测値と計算値との差が最小となるよう に設定した。 その結果は後述する。

沖波波高・周期・波向，および観測栈橋先端における 風速，風向の月平均を図-3に示す，沖波波高は $1 \sim 3$ 月および 9 〜 10 月にかけて大きく，6〜8月にかけて

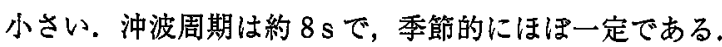
波向に関しては，12２月には北からの入射が多く，5 〜9月には南からの入射が多くなっている. 風況として は，10〜2月にかけては強い風が北から入射するのに 対して，5８月にかけては弱い風が南から入射するこ とが多い.

計算の沖側境界は P925m 地点（地盤高さ D.L. -8.28 m）に設定し，格子間隔は $10 \mathrm{~m}$ とした，断面地形とし ては，栈橋先端の P385 m 地点より岸側では毎日の観測 データを用い，P445 m よりの沖側では年 1〜2回実施 している栈橋先端より沖の深浅測量結果の平均值を用い る. P445 m 〜 P385 m の領域では, P445 $\mathrm{m}$ と $\mathrm{P} 385 \mathrm{~m}$ の地盤高さを用いて線形補間した值を用いる。平均水位 としては沿岸流速観測時の潮位を与え，境界条件として は，沖側境界と汀線において沿岸流速値を0と設定した。

各観測值点における沿岸流速の実測值と計算值との誤 差の二乗の総和が最小となるように試行錯誤によって得 られた倸数は $k_{a}=1.09 \mathrm{~m}, \alpha=1.4$ であり, 補正角度 $\theta_{c}$

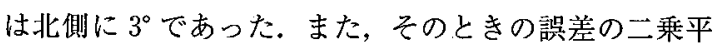
均平方根值は $0.22 \mathrm{~m} / \mathrm{s}$ であった.

以上の值を用いて求めた $\mathrm{P} 380 \mathrm{~m}$ 地点と $\mathrm{P} 115 \mathrm{~m}$ 地点 における沿岸流速の計算値と実測值とを比較したものが 
図-4，長期間平均した沿岸流速の岸沖分布の計算值と実 測值とを比較したものが図-5である．图-4より，計算 值に多少のバラッキはあるものの，岸，沖ともに計算值 は実測値を比較的精度良く再現している，また，長期平 均の沿岸流速に関しては（図-5)，計算值は，岸では北
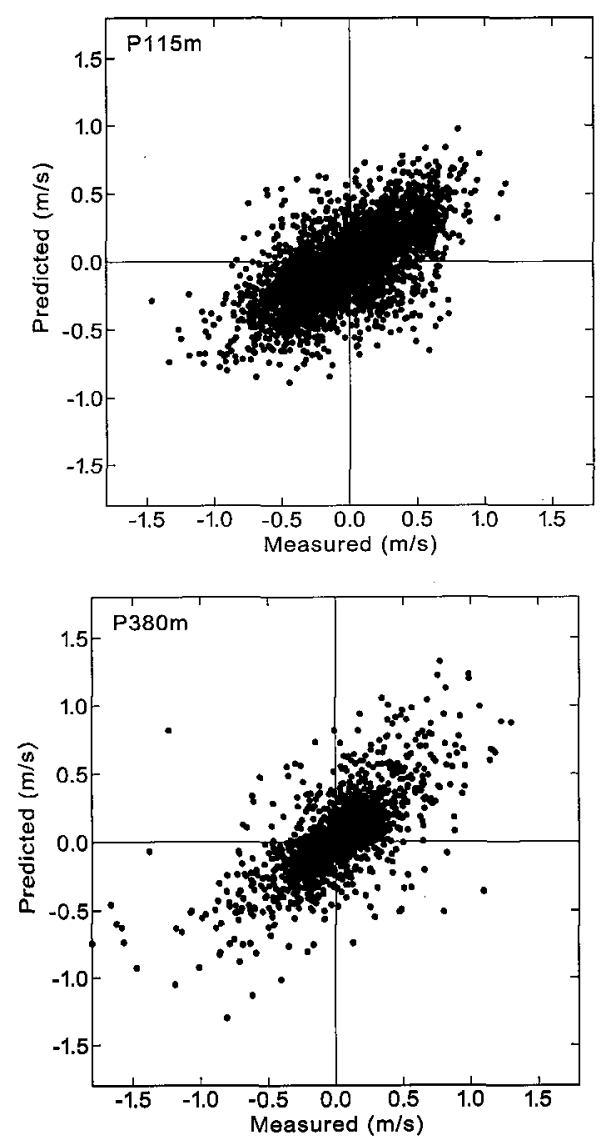

図-4P115m 地点（上図, 汀線近傍の基準点より $115 \mathrm{~m}$ 沖側の地点) および $\mathrm{P} 380 \mathrm{~m}$ 地点（下図）におけ る沿岸流速の実測值と計算值との比較

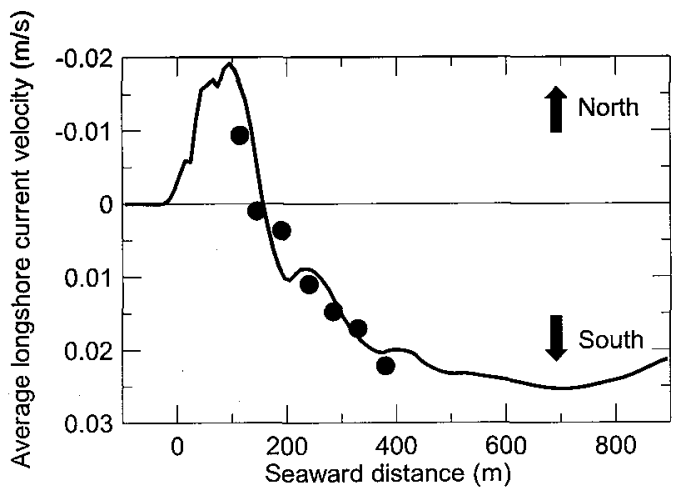

図-5 長期間平均の沿岸流速の岸沖分布の実測値（黒丸 印）と計算值（実線）との比較

向き，沖では南向きの沿岸流が卓越するという現地の長 期平均沿岸流の特徴を定性的にも定量的にも良く表現し ている．なお，長期の沿岸流速の方向が岸と沖で翼なる 原因は，北向き，南向きの沿岸流が生じた場合の波浪と 風の特性が異なっていたことにあり，その詳細な検討は 栗山ら（2005）によって行われている.

\section{4. 沿岸漂砂量の推定および考察}

沿岸漂砂量の計算期間は沿岸流速推定サブモデルのキ ヤリブレーション期間と同様の 1987 年 1 月 2001 年 12 月までの 15 年間であり, 計算の時間間隔は 2 時間で ある. 粒径は $0.2 \mathrm{~mm}$ とし, 係数 $A$ の值は, 清水 (1996) に示されている漂砂量係数に関する既往の研究 例を参考に 2.0 とした．限界シールズ数としては，粒径 $0.2 \mathrm{~mm}$ とすると Madsen・Grant（1976）によって示 されている定常流に対する限界シールズ数曲線からは 0.05, 土屋（1986）加は 0.07 が求まることから，本 研究では $\Psi_{c r}=0.06$ とした. 図-6 は $\mathrm{P} 115 \mathrm{~m}$ 地点での沿 岸漂砂量の計算值の向きが北向き，南向きであった場合 のそれぞれの沿岸漂砂量を計算期間累積した值を基に求 めた， 1 年当たりの北向き，南向きの沿岸漂砂量の絶対 值の岸沖分布を示したものであり，図-7 は平均沿岸漂 砂量の岸沖分布を示したものである。

図-6に示されている計算值を基に，汀線から水深 7 $\mathrm{m}$ の地点（P735 m 地点）まで積分した北向き，南向き の 1 年当たりの沿岸漂砂量の值は，それぞれ 469,000 , $596,000 \mathrm{~m}^{3}$ /year であり, Sato・Tanaka (1966) が梁 浅図を基に求めた水深 $7 \mathrm{~m}$ までの北向き, 南向きの 1 年 当たりの沿岸漂砂量 約 $600,000 \mathrm{~m}^{3} /$ year とほほ一致し た.この結果は, 本研究で用いたモデルの妥当性を示し ている.

一方，平均沿岸漂砂量の岸沖分布（図-7）を見てみる と, 波崎海岸では岸と沖とで平均沿岸漂砂量の向きが異

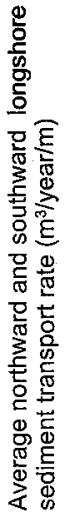

図-6 北向き，南向きの 1 年当たりの沿岸漂砂量の絶対 值の岸沖分布 


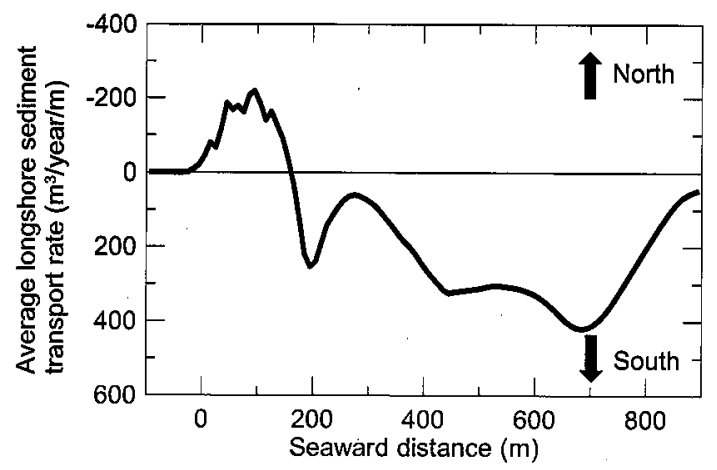

図-7 平均沿岸漂砂量の岸沖分布

なっていたすなわち，岸では北向き漂砂が卓越してい たのに対して, 汀線から約 $150 \mathrm{~m}$ 沖の地点よりも沖側 では南向き漂砂が卓越していた，汀線近傍の平均汾岸漂 砂の向きは，航烓写真を基にした汀線変動より推定され た沿岸漂砂の向き（例えば，田中ら，1980）と一致して おり,この結果も本研究における結論の妥当性を示して いると言える。

本研究の成果は，異なる向きの沿岸流が生じたときの 波浪や風の特性が異なっている場合には，Sato（1996） が示唆したように卓越沿岸漂砂の向きが岸と沖で異なる 可能性があることを示している，構造物の漂砂下手側の 汀線近傍において沿岸漂砂の不均衡による海岸侵食が生 じており，岸の沿岸漂砂の卓越方向と沖のそれとが異な っている場合には, 沖の砂をサンドバイパスの供給源と して利用することが可能かもしれない。

今後は, 本モデルの特に砕波帯外の沿岸漂砂量に対す る現地適用性をより詳細に検討するとともに，他海岸に おける長期平均沿岸漂砂量の岸沖分布を検討する予定で ある。

\section{5. 結}

\section{論}

本研究では，茨城県波崎海岸で取得した沿岸流速デー タを用いてキャリブレーションした沿岸漂砂量推定モデ ルを基に，沿岸漂砂量の岸沖分布を 2 時間ごとに 15 年 間分計算し，それらを平均することにより平均沿岸漂砂 量の岸沖分布を求めた. その結果, 平均沿岸漂砂量の向 きは岸と沖で異なっており，岸では北向き漂砂が卓越し ていたのに対して，汀線から約 $150 \mathrm{~m}$ 沖の地点よりも 沖側では南向き漂砂が卓越していたことが明らかとなっ た.

本研究の結論は, 波浪や風の条件によっては, 沖の砂 を海岸保全のためのサンドバイパスの供給源として利用 することが可能であることを示唆している。
謝辞：本研究で使用した沖波データは国土交通省鹿島港 湾 ·空港整備事務所と当所海象情報研究室より提供され たものである、また，本研究で使用した地形データは， 波崎海洋研究施設に常駐した当所漂砂研究室のメンバー ならびに（株）エコーの観測補助員によって取得された ものである.ここに記して謝意を表する。

\section{参 考 文 献}

加藤一正 ·柳嶋慎一 - 栗山善炤 - 磯上知良 - 村上裕幸 - 藤田 誠 (1990)：砕波带内の底質粒径の変動特性一波崎海洋研究 施設における現地調査一, 港研報告, 29 巻, 2 号, pp. $37-61$.

栗山善昭 - 加藤一正 - 尾崎 靖 (1992): 沿岸流速分布の類型化 と支配要因の検討, 海岸工学諭文集, 39 巻, pp. 196-200.

栗山善昭・中官利之 (1999): 沿岸砂州周辺の戻り流れ・沿岸流 推定モデル, 土木学会論文集, No. 635 , pp. 97-111.

栗山善昭 ・伊東啓勝・柳嶋慎一 (2005) : 長期現地観测データに 基づく卓越沿岸流の岸沖分布の検討, 土水学会論文集, No. 803/II-73, pp. 145-453.

清水玩三 (1996)：海浜変形シミュレーション, 1996 年度(第 32 回) 水工学に関する夏期研修会講義集, B コース, pp. B-5-1-B-5-26.

田中則男・小山内英雄・夷塚葉子 (1980)：我が主要海浜の特性 について，港湾技研資料，No. $356 ， 67 \mathrm{p}$.

土屋義人 (1986)：漂砂量則について，第 22 回水工学に関する 夏期研修会講義集, pp. 1-22.

西村仁嗣 (1982)：海浜循環流の数值シミュレーション，第 29 回海講論文集, pp. 333-337.

橋本典明・川口浩二・真期俊行・永井紀彦 (1999)：第 3 世代波 浪推算法 (WAM) の推算精度に関する検討, 港研報告, 第 38 巻, 第 4 号, pp. 3-47.

渡辺 晃 - 丸山康樹 - 清水隆夫 ·榊山 勉 $(1984)$ : 構造物設置 に伴う三次元海浜変形の数値予測モデル，第 31 回海講論 文集, pp. 406-410.

Battjes, J.A. (1975); Modeling of turbulence in the surf zone, Symp. on Modeling Techniques, pp. 1050-1061.

Garcez-Faria, A.F., E.B. Thornton, T.P. Stanton, C.V. Soares, and T.C. Lippmann (1998):Vertical profiles of longshore currents and related bed shear stress and bottom roughness, J. Geophysical Res., Vol. 103, No. C2, pp. $3217-3232$.

Kuriyama, Y. and Y. Ozaki(1996) : Wave height and fraction of breaking waves on a bar-trough beach -Field measurements at HORS and modeling-, Rep. Port and Harbour Res. Inst., Vol. 35, No. 1, pp. 1-38.

Kuriyama, Y. (2002):Medium-term bar behavior and associated sediment transport at Hasaki, Japan, J. Geophysical Res., Vol. 107, No. C9, 3132, doi:10.1029/2001JC000899.

Madsen, O.S. and W.D. Grant (1976): Quantitative description of sediment transport by waves, Proc. 15th ICCE, pp. 1093-1112.

Ruessink, B.G., J.R. Miles, F. Feddersen, R.T. Guza and S. Elgar (2001) :Modeling the alongshore current on barred beaches, J. Geophysical Res., Vol. 106, No. C10, pp. 22451-22463.

Sato, S. and N. Tanaka (1966) : Field investigation on sand drift at Port Kashima facing the Pacific Ocean, Proc. 10th ICCE, pp. 595-614.

Sato, S. (1996) :Effects of winds and breaking waves on large-scale coastal currents developed by winter storms in Japan Sea, Coastal Eng. in Japan, Vo. 39. No. 2. pp. 129-144. 